\title{
Drainage water management effects over five years on water tables, drainage, and yields in southeast lowa
}

\author{
L. Schott, A. Lagzdins, A.L.M. Daigh, K. Craft, C. Pederson, G. Brenneman, and M.J. Helmers
}

\begin{abstract}
Subsurface drainage improves row crop production but also short circuits nitrate-nitrogen $\left(\mathrm{NO}_{3}-\mathrm{N}\right)$ pathways in the soil with significant losses to surface waters. The objective of this study was to evaluate the effect of shallow, controlled, conventional, and undrained drainage treatments on depth to water table, drainage volume and $\mathrm{NO}_{3}-\mathrm{N}$ loads, soil water content and storage in the soil profile, and crop yields. This research was conducted at the Iowa State University Southeast Research Farm near Crawfordsville, Iowa, from 2007 to 2015. We report on years five through nine here. The site consisted of eight large field plots with each of the four drainage treatments replicated twice. One-half of each plot was planted with corn (Zea mays L.) and the other half with soybeans (Glycine max [L.] Merr.). The corn and soybean halves were rotated every year in accordance with a typical corn-soybean rotation. The undrained treatment had a shallower water table than the other treatments and had a significantly higher number of days during the growing season when the water table was within $30 \mathrm{~cm}$ (12 in) of the ground surface than the other treatments. However, there was no difference in soil water contents in the top $80 \mathrm{~cm}(31.5 \mathrm{in})$ of the soil profile during the growing season between drainage treatments. Over the five-year study, controlled and shallow drainage reduced annual subsurface flows by $60 \%$ and $58 \%$, respectively, while also reducing $\mathrm{NO}_{3}-\mathrm{N}$ loads by $61 \%$ and $49 \%$, respectively, as compared to the conventional drainage design. Crop yields were similar along the drainage designs but significantly lower in the undrained treatment. This study highlights the effectiveness of shallow and controlled drainage to reduce $\mathrm{NO}_{3}-\mathrm{N}$ loads.
\end{abstract}

Key words: drainage water management—nitrate—volumetric water content—water table

\begin{abstract}
Shallow water tables increase the risk of soil compaction during field activities and contribute to excess water-stress to crops (Skaggs and van Schilfgaarde 1999).

Subsurface drains lower shallow water tables and remove excess water from soil profiles with poor natural drainage, which consequently improves soil strength and aeration. However, subsurface drains are well known to short-circuit nutrient pathways in the soil profile and export nitrate-nitrogen $\left(\mathrm{NO}_{3}-\mathrm{N}\right)$ in drainage waters from agricultural lands in the Mississippi River Basin to the Gulf of Mexico, contributing to the hypoxic zone (Turner and Rabalais 1994; David et al. 2010).

Drainage water management reduces and sometimes eliminates drainage, and thus $\mathrm{NO}_{3}-\mathrm{N}$ losses, during periods of the year. Drainage water management may consist
\end{abstract}

United States and Canada when compared to conventional drainage.

The cost of implementing drainage water management systems can be a drawback to some producers if there is not a yield benefit. The higher costs of these systems as compared to conventional drainage derive from the extra materials and labor required for their installation (Frankenberger et al. 2007; Sands et al. 2008). Shallower drains require more closely spaced drains and undulating fields require additional control structures. Achieving high crop yields typically means retaining optimal soil moisture throughout the growing season (Skaggs and van Schilfgaarde 1999). Soil water content is important to plants and their health because it influences gas exchange and diffusion of nutrients to plant roots. The force with which the water is held in the soil matrix affects how much water can be adsorbed by plants and the drainage of excess water by gravity (Jury and Horton 2007). The depth to water table, which is altered with subsurface drainage, affects the soil water content and amount of water stored in the soil profile (Madramootoo 1993; Skaggs and Chescheir 2003). However, frequent monitoring of soil water contents and water storage in drainage water management systems is uncommon due to the cost of sensors and data loggers.

Across the 20 research sites summarized by Skaggs et al. (2012), crop yields either stayed the same or increased up to $10 \%$ and $19 \%$ for soybean (Glycine max L. Merr.) and corn (Zea mays L.), respectively, on the controlled drainage treatments as compared

Linda Schott is a graduate student in the Department of Biological Systems Engineering at University of Nebraska-Lincoln, Lincoln, Nebraska. Ainis Lagzdins is an associate professor in the Department of Environmental Engineering and Water Management at Latvia University of Agriculture, Jelgava, Latvia. Aaron L.M. Daigh is an assistant professor in the Soil Science Department at North Dakota State University, Fargo, North Dakota. Kristina Craft is a graduate student in the Department of Agricultural and Biosystems Engineering at lowa State University, Ames, lowa. Carl Pederson is an agricultural specialist in the Department of Agricultural and Biosystems Engineering at lowa State University, Ames, lowa. Greg Brenneman is a field specialist in Extension to Agriculture at lowa State University, Ames, lowa. Matthew J. Helmers is a professor in the Department of Agricultural and Biosystems Engineering at lowa State University, Ames, lowa. 
to the conventionally drained treatments. However, controlled drainage during the first four years at our research site significantly reduced corn yields when averaged across four years (2007 to 2010) but not within any individual year or for plots planted to soybean (Helmers et al. 2012). The direct comparison of shallow, controlled, conventional, and undrained drainage systems at the same site is rare and thus the scientific literature is limited in side-by-side evaluations of these systems. Therefore, the objectives of this study were to evaluate the effect of shallow, controlled, conventional, and undrained drainage treatments on depth to water table, drainage volume and $\mathrm{NO}_{3}-\mathrm{N}$ loads, soil water content and storage in the soil profile, and crop yields at a single midwestern field in years five through nine after drain installation. This study extends on the data and results reported for years one through four in Helmers et al. (2012) in order to evaluate drainage water management over a wider range of weather conditions.

\section{Materials and Methods}

Site Location and Design. Research was conducted at the Iowa State Southeast Research Farm (SERF) near Crawfordsville, Iowa $\left(41^{\circ} 11^{\prime} 38^{\prime \prime} \mathrm{N}, 91^{\circ} 28^{\prime} 58^{\prime \prime} \mathrm{W}\right)$. The drainage plots were established in 2007 and became part of the USDA National Institute of Food and Agriculture (NIFA)-funded Climate and Corn-based Cropping Systems Coordinated Agricultural Project from 2011 to 2015 (sustainablecorn.org). Data from 2007 to 2010 on the water table depths, drainage, and crop yields were reported in Helmers et al. (2012), along with the site description, plot layout, and methods. The treatments and methods have remained the same from 2007 through 2015. Additional site details are described in Helmers et al. (2012).

The site consists of eight research plots, each ranging in size from 1.2 to 2.4 ha (3 to 6 ac). Drainage treatments include undrained, conventional drainage, shallow drainage, and controlled drainage plots replicated twice (figure 1). The plots were blocked into a north and south replication because the site consisted of two poorly drained silty clay loam soils. The north plots predominately lay over Kalona (silty clay loam, fine, smectitic, mesic Vertic Endoaquolls) soil series whereas the south plots lay over Taintor (silty clay loam, fine, smectitic, mesic Vertic Argiaquolls) soil series. The site is relatively flat with less than a $5 \mathrm{~m}$ (16 ft) elevation change over the total 17 ha $(42 \mathrm{ac})$ site. The plots were designed to have a maximum drainage coefficient of $1.9 \mathrm{~cm} \mathrm{~d}^{-1}(0.75$ in day $\left.^{-1}\right)$. The conventional and controlled drainage plots had a drain depth and spacing of 1.2 and $18 \mathrm{~m}$ (4 and $60 \mathrm{ft}$ ), respectively. The shallow drained plots had drains at a depth and spacing of 0.76 and $12.2 \mathrm{~m}(2.5$ and $40 \mathrm{ft}$ ), respectively.

Originally, half of each plot was planted to corn and half to soybeans, and the halves were alternated each consecutive year to replicate a typical corn-soybean rotation in Iowa. In 2012, however, 24 rows of continuous corn were added on the north and south edges of the site, so each plot had rotational corn, rotational soybeans, and continuous corn every year creating three subplots per drainage plot (figure 1). Subplots were chisel plowed in the fall following corn, and all subplots were field cultivated prior to planting. For subplots planted to corn, anhydrous ammonia $\left(\mathrm{NH}_{3}\right)$ was applied in the spring prior to planting at a rate of $169 \mathrm{~kg} \mathrm{~N} \mathrm{ha}^{-1}$ and $224 \mathrm{~kg} \mathrm{~N} \mathrm{ha}^{-1}$ (150 $\mathrm{lb} \mathrm{N} \mathrm{ac}{ }^{-1}$ and $200 \mathrm{lb} \mathrm{N} \mathrm{ac}^{-1}$ ) for rotational and continuous corn, respectively.

At this site, the boards in the controlled drainage treatment were removed in mid to late April approximately two weeks prior to planting to allow free drainage and replaced in late May to early June after planting was completed to a depth of $76 \mathrm{~cm}$ (30 in). Due to water tables being below $1 \mathrm{~m}(3.3$ $\mathrm{ft})$, boards were not removed to allow free drainage in 2013 and 2014. Thus, drainage depth was $76 \mathrm{~cm}$ (30 in) for the entirety of these years. Removal of the boards prior to harvest in the fall was not necessary due to deep water table conditions. Dates of planting, harvest, and moving boards in the controlled drainage structures for each year are listed in table 1.

Data Collection. Daily rainfall was measured using a manually read rain gauge located approximately $1 \mathrm{~km}$ (0.62 mi) from the research plots from 2011 to 2015. At the end of December of 2013, a weather station, part of the Iowa State University Soil Moisture Network, containing a nonheated tipping bucket was installed adjacent to the research plots, which provided higher resolution rainfall data. As a result, beginning in 2014, the two rainfall data sets were averaged to obtain a better representation of precipitation at the field site level. The 50-year precipitation averages were obtained from the National Weather Service Cooperative Observer Program for Mount Pleasant, located approximately $15 \mathrm{~km}$ (9.3 mi) away (table 2).

Methodologies for monitoring drainage flow volume, drainage water quality, depth to water table, and yield were outlined previously by Helmers et al. (2012). In order to address the differences in plot size, drainage volumes were normalized and reported as the depth of drainage. Standardized protocols agreed upon by the USDA NIFAfunded Climate and Corn-based Cropping Systems Coordinated Agricultural Project were followed when measuring soil carbon (C), N, texture, bulk density, soil volumetric water content (VWC), and soil temperature (Kladivko et al. 2014). Briefly, soil moisture sensors, ECH20 5TM (Decagon, Pullman, Washington) were installed in the center of the continuous corn portion of each plot in 2011. VWC and temperature were measured at the following five depths: 10, 20, 40, 60, and $100 \mathrm{~cm}$ (4, 8, 16, 24, and $39 \mathrm{in})$. Maximum VWC values were capped to individual plot total soil porosity at the sensor depth increment. Average daily VWC was calculated for the top four depths, and average daily soil water storage from 0 to $80 \mathrm{~cm}$ (0 to 31.5 in) was calculated using weighted depth increments ( 0 to 15,15 to 30,30 to 50 , and 50 to $80 \mathrm{~cm}$ [0 to 6,6 to 12,12 to 20 , and 20 to $31.5 \mathrm{in}]$ ) for the top four sensors. Research data were uploaded to the team's central database with review and quality control performed by database managers to ensure data integrity and adherence to standardization (Herzmann et al. 2014).

Statistical Analysis. The experimental design was a randomized complete block design for the drainage treatments. Statistical analyses were conducted using Statistical Analysis System software (version 9.4 SAS, 2011). The general linear model (GLM) procedure was used with two replicates per treatment to determine the statistical significance of treatment effects on subsurface drainage volume, crop yield, soil total $\mathrm{C}$ and $\mathrm{N}$ stocks, flow-weighted $\mathrm{NO}_{3}-\mathrm{N}$ concentration, $\mathrm{NO}_{3}-\mathrm{N}$ loads, and days the water table depth was less than 30 and $60 \mathrm{~cm}$ (12 and 24 in) from the soil surface. The mean values for subsurface drainage volume, crop yield, soil $\mathrm{C}$ and $\mathrm{N}$ stocks, flow-weighted $\mathrm{NO}_{3}-\mathrm{N}$ concentration, $\mathrm{NO}_{3}-\mathrm{N}$ loss, and days the water table depth was less than of 30 and $60 \mathrm{~cm}$ from the soil surface were separated using a least significance difference (LSD) test at 


\section{Figure 1}

Aerial view of drainage plots in 2012 when 24 rows on the northern and southern sides of the field were removed from rotation for continuous corn. The map illustrates data collection locations, drainage layout, and cropping system.
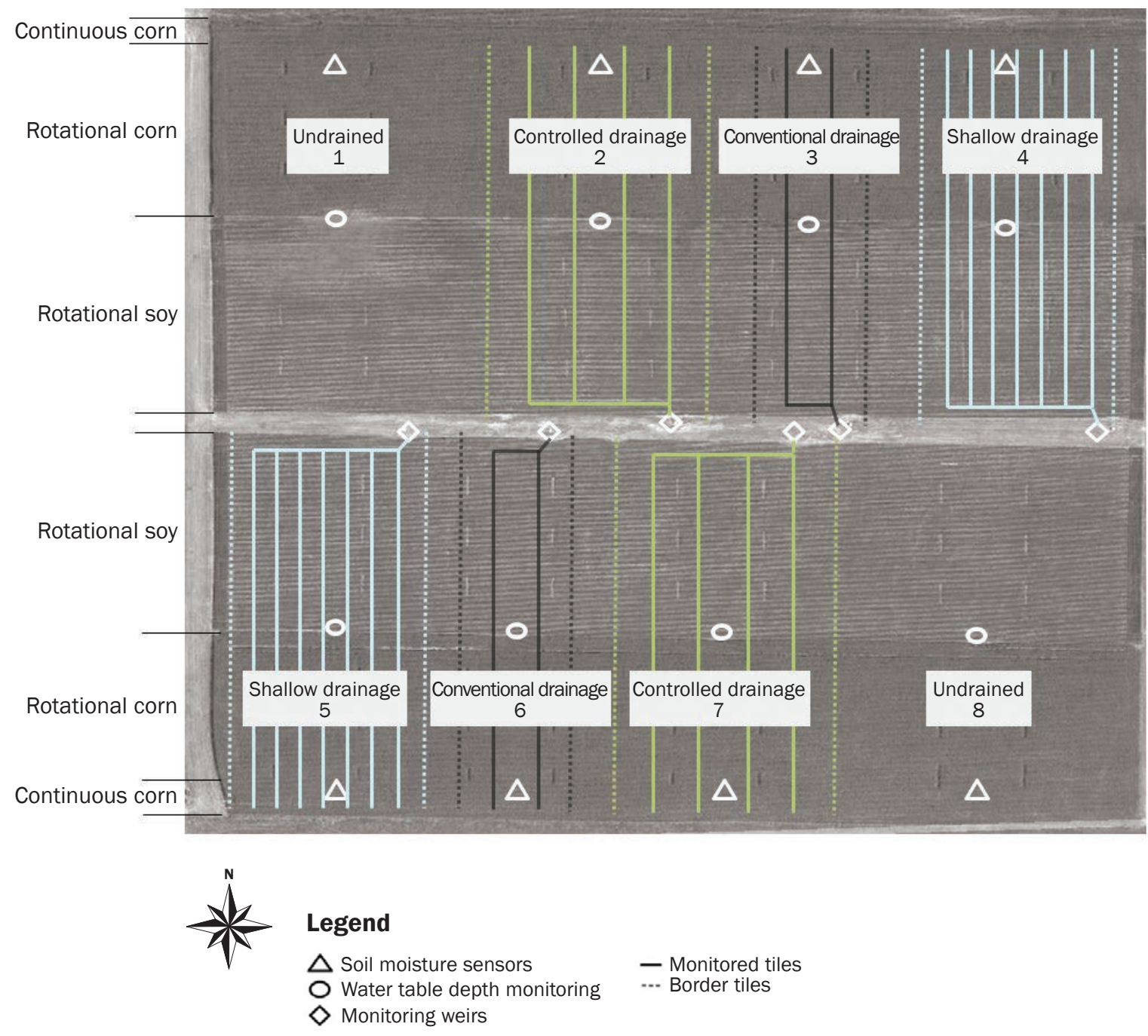

\section{Table 1}

Field activities from 2011 to 2015, including control dates for controlled drainage plots. An open control structure indicates the drainage depth is $1.2 \mathrm{~m}$. In the spring, a closed control structure indicates drainage depth is $0.76 \mathrm{~m}$. If no date is given, boards remained closed for the entire year.

\begin{tabular}{lllllll}
\hline & Corn & \multicolumn{3}{c}{ Soybean } & \multicolumn{3}{c}{ Spring control } \\
\cline { 2 - 6 } Year & Planting & Harvest & Planting & Harvest & Open & Close \\
\hline 2011 & May 3 & Sept. 29 & May 11 & Oct. 3 & Apr. 19 & June 1 \\
2012 & Apr. 18 & Sept. 24 & May 15 & Oct. 24 & Apr. 5 & June 14 \\
2013 & May 17 & Oct. 4 & June 12 & Oct. 2 & - & All year \\
2014 & May 19 & Nov. 7 & June 9 & Oct. 10 & - & All year \\
2015 & Apr. 30 & Sept. 15 & May 2 & Oct. 7 & Mar. 31 & May 22
\end{tabular}


Table 2

Seasonal monthly rainfall ( $\mathrm{mm}$ ) at the lowa State Southeast Research Farm (SERF) from 2011 to 2015, including a long-term average at Mount Pleasant, approximately $15 \mathrm{~km}$ away.

\begin{tabular}{lrrrrrrrrr}
\hline Year & Mar. & Apr. & May & June & July & Aug. & Sept. & Oct. & Season \\
\hline 2011 & 46 & 96 & 144 & 208 & 33 & 26 & 45 & 15 & 612 \\
2012 & 29 & 70 & 159 & 89 & 13 & 121 & 69 & 89 & 638 \\
2013 & 60 & 189 & 259 & 103 & 29 & 2 & 44 & 111 & 798 \\
2014 & 4 & 83 & 46 & 270 & 63 & 72 & 122 & 118 & 778 \\
2015 & 8 & 65 & 118 & 247 & 145 & 107 & 76 & 52 & 819 \\
50 -year average & 61 & 91 & 120 & 121 & 114 & 106 & 105 & 75 & 793 \\
\end{tabular}

$\mathrm{Mg} \mathrm{C} \mathrm{ha}{ }^{-1}\left(5.88[ \pm 0.14]\right.$ tn $\left.\mathrm{C} \mathrm{ac}^{-1}\right)$ and 0.89 $( \pm 0.03) \mathrm{Mg} \mathrm{N} \mathrm{ha}^{-1}\left(0.40[ \pm 0.01]\right.$ tn $\left.\mathrm{N} \mathrm{ac}^{-1}\right)$ and did not differ among plots. Similarly, soil bulk density in the 0 to $60 \mathrm{~cm}$ soil profile was $1.36( \pm 0.02) \mathrm{Mg} \mathrm{m}^{-3}\left(1 \mathrm{tn} \mathrm{yd}^{-3}\right)$ and was not affected by drainage treatment.

Precipitation. The 50-year average of seasonal rainfall at SERF from March to October is $793 \mathrm{~mm}$ (31.2 in; table 2). In years 2011 and 2012, SERF received 23\% and $20 \%$ below average rainfall, respectively, whereas years 2013, 2014, and 2015 received near average rainfall. Near average rainfall was observed during the spring of 2011 followed by below average rainfall. Above average rainfall ensued in the spring of 2013 followed by a dry summer. In contrast, 2014 had a reverse seasonal rainfall pattern with below average rainfall in the spring and above average rainfall in the summer. This pattern was also observed at other research sites across Iowa (Daigh et al. 2015; Basche et al. 2016; Martinez-Feria et al. 2016). In three of the five years, October received above average rainfall.

Water Table. Depth to water table was unaffected by drainage treatment for the five-year period, but there were annual differences between some treatments. Water tables in the undrained treatment were shallower than the conventional and controlled drainage treatments in 2011, 2013, and 2014; the undrained treatment was also shallower than the conventional treatment in 2015. The water table in the shallow drainage treatment was shallower than the conventional treatment in 2013, 2014, and 2015. The lack of statistical differences between the drainage treatments over the entire five years is likely due to rainfall patterns. The water tables were likely deep enough to not be affected by the drainage management, but instead by larger scale regional groundwater flows. The study period included many months of below average rainfall causing deep water tables across all treatments. Water tables were the deepest in 2012 and shal- lowest in 2015. Overall, water tables were typically the deepest in the summer, fall, and winter months while shallowest in the spring months. Water tables were also statistically shallower in the northern replication, which was expected due to the Kalona soil series having characteristics of a seasonally high water table (i.e., Endoaquoll).

There are, however, numerous instances when depth to water table differed between treatments monthly (table 3). In 2011, the undrained treatment had the shallowest water table with an average depth between 50 and $60 \mathrm{~cm}$ (20 and 24 in) in April, May, and June during field activities and crop establishment. During this time period, there were no monthly differences between the three drained treatments. Boards in the controlled drainage structures were maintained at 76 cm (30 in) depth for all of 2013 due to the previous year's drought. However, depth to water table did not differ between the conventional and controlled drainage treatments from April to July when the boards of the control structures would typically have been removed to allow unrestricted drainage. Water tables in the shallow and undrained treatments were significantly shallower than the conventional treatment during this same period from April to July in 2013. Shallower water tables in the undrained treatment also occurred during the spring months of 2014 and 2015. Water tables in the shallow drainage treatment were significantly shallower than the conventional treatment from October of 2014 through July of 2015 (table $3)$. In contrast, the controlled drainage did not differ from the conventional drainage system during all of 2014 and 2015 (table 3).

When the water table is within $30 \mathrm{~cm}$ (12 in) of the soil surface, there is a greater risk of excess water stress to the crop, which can result in yield reductions (Skaggs and van Schilfgaarde 1999). Plant stress due to changes in cell-water relations can occur within minutes with consequences to plant growth (Passioura and Munns 2000; Munns
2002). However, no long-term effects to total plant biomass or yields occur if the stress is short lived (i.e., minutes to hours). If the stress persists for longer periods of time (i.e., days to weeks), yields and plant survival decrease as a function of time, which is crop specific. For corn and soybean crops, significant effects on crop yields have been reported for soil conditions that limit adequate soil aeration (i.e., delivery of oxygen [O] and removal of root-derived carbon dioxide $\left[\mathrm{CO}_{2}\right]$ ) for two, three, or more consecutive days (Lizaso and Ritchie 1997; Lauer 2008). Our objective in this study was not to elucidate a specific cumulative duration of limited soil aeration that would significantly affect crop yields (i.e., consecutive hours or days following a saturating precipitation event). Instead, we aimed to evaluate the effect of crop yields as a function of total cumulative days within a growing season in which the water table was within $30 \mathrm{~cm}$ of the soil surface. Since each plot received the same amount of precipitation and each subsurface drainage treatment was designed to have the same drainage coefficient, each plot has the same potential for short-lived periods (e.g., less than two, three, or more consecutive days) of water stress without consequence to the final yields (i.e., the same baseline conditions or intercept during the statistical analysis). Therefore, our analysis of crop yields as a function of total cumulative days of high water tables during the growing season has the benefit of capturing all periods of water stress to the crop that would otherwise potentially be missed by choosing an unprecise, and therefore arguably arbitrary, accumulation of consecutive periods with high water tables (i.e., cumulative periods with water stress occurring over two, three, or more days).

As expected, the undrained treatment had the greatest number of days the water table was within $30 \mathrm{~cm}$ (12 in) of the ground for all five years (6 to 26 days; table 4 ). Shallow drainage had the second highest number of 
Table 3

Average monthly depth to water table (cm) from 2011 to 2015 for the four treatments: conventional drainage (Conv.), controlled drainage (CD), shallow drainage (SH), and no drainage (ND). Dashes indicate unavailable data. Means within months with a different letter are significantly different $(p<0.05)$. Only months with significant differences have letters included.

\begin{tabular}{|c|c|c|c|c|c|c|c|c|c|c|c|c|c|c|c|c|c|c|c|c|}
\hline \multirow[b]{2}{*}{ Month } & \multicolumn{4}{|l|}{2011} & \multicolumn{4}{|l|}{2012} & \multicolumn{4}{|l|}{2013} & \multicolumn{4}{|l|}{2014} & \multicolumn{4}{|l|}{2015} \\
\hline & Conv. & $C D$ & SH & ND & Conv. & $C D$ & SH & ND & Conv. & $C D$ & SH & ND & Conv. & $C D$ & SH & ND & Conv. & $C D$ & SH & ND \\
\hline Jan. & $144 a b$ & $146 a$ & $152 a$ & $108 b$ & 178 & 200 & 160 & 179 & 172 & 185 & 156 & 162 & - & - & - & - & $150 a$ & $140 a$ & $104 b$ & $125 a b$ \\
\hline Feb. & $135 a b$ & $142 a$ & $144 a$ & $101 b$ & 177 & 192 & 160 & 176 & 162 & 155 & 154 & 118 & - & - & - & - & $151 a$ & 139ab & $109 b$ & $126 a b$ \\
\hline Mar. & $134 a$ & $120 a$ & $118 a$ & $52 b$ & 177 & 192 & 160 & 172 & $136 a$ & $116 a$ & $97 a b$ & $69 b$ & - & - & - & - & $152 a$ & $140 a b$ & $111 b$ & $131 \mathrm{ab}$ \\
\hline Apr. & $134 a$ & $125 a$ & $119 a$ & $63 b$ & 180 & 189 & 159 & 152 & $121 a$ & $98 a b$ & $49 b c$ & $47 c$ & 174 & 189 & 161 & 164 & $150 a$ & $142 a b$ & $106 c$ & $121 b c$ \\
\hline May & $130 a$ & $127 a$ & $117 a$ & $48 b$ & $129 a$ & $111 \mathrm{ab}$ & $73 a b$ & $66 \mathrm{~b}$ & $124 a$ & $109 a b$ & $57 \mathrm{bc}$ & $61 c$ & 179ab & $189 a$ & $164 a b$ & $146 b$ & $142 a$ & $129 a$ & $77 b$ & $97 b c$ \\
\hline June & $126 a$ & $122 a$ & $105 a$ & $52 b$ & 147 & 134 & 96 & 100 & $149 a$ & $127 a b$ & $72 b$ & $83 b$ & $158 a$ & $150 a$ & $122 a b$ & $100 b$ & $131 a$ & $108 a$ & $64 b$ & $77 b c$ \\
\hline July & $142 a$ & $144 a$ & $135 a b$ & $101 b$ & 177 & 173 & 144 & 142 & $165 a$ & $134 a b$ & $93 b$ & $112 b$ & $153 a$ & 119ab & $81 b$ & $84 b$ & $143 a$ & $125 a$ & $81 b$ & $76 b c$ \\
\hline Aug. & $185 a$ & $188 a$ & $169 a b$ & $137 b$ & 188 & 204 & 160 & 182 & 192 & 179 & 146 & 152 & 180 & 169 & 137 & 140 & $142 a b$ & $144 a$ & $109 b c$ & $86 c$ \\
\hline Sept. & 193 & 197 & 170 & 173 & 188 & 204 & 160 & 166 & $209 a$ & $187 a$ & $166 a b$ & $132 b$ & $167 a$ & $161 a$ & $142 \mathrm{ab}$ & $119 b$ & $150 a$ & $146 a$ & $128 a$ & $81 b$ \\
\hline Oct. & 181 & 201 & 170 & 178 & 187 & 189 & 160 & 174 & $209 a$ & $187 a$ & $165 a b$ & $137 b$ & $130 a$ & $114 a b$ & $79 b c$ & $70 c$ & $148 a$ & $132 a$ & $125 a b$ & $91 b$ \\
\hline Nov. & 176 & 199 & 169 & 174 & 189 & 191 & 161 & 173 & $214 a$ & $187 a b$ & $165 a b$ & $154 b$ & $141 a$ & $129 a b$ & $91 b$ & $105 a b$ & - & - & - & - \\
\hline Dec. & 175 & 193 & 169 & 174 & 177 & 192 & 161 & 168 & $216 a$ & $188 a b$ & - & $162 b$ & $140 a$ & $131 a b$ & $87 b$ & $108 a b$ & - & - & - & - \\
\hline
\end{tabular}

days while the controlled and conventionally drained treatments were similar (table 4). Optimal water table depth for corn growth is $60 \mathrm{~cm} \mathrm{(24} \mathrm{in)} \mathrm{from} \mathrm{the} \mathrm{ground} \mathrm{surface}$ (Drury et al. 1997). No drainage had the greatest number of days that the water table was between 30 and $60 \mathrm{~cm}$ (12 and 24 in). However, there were no differences between the three drainage treatments. In 2013 and 2014, the shallow and undrained treatments were similar in the number of days the water tables were within $60 \mathrm{~cm}$ of the ground surface. Interestingly, even though the boards in the controlled drainage structure were maintained at $76 \mathrm{~cm}$ (30 in) throughout the 2013 and 2014 growing season, the number of days the water table was within $60 \mathrm{~cm}$ of the ground surface was not different between the controlled drainage and conventional drainage treatments (table 4).

Volumetric Water Content and Soil Water Storage. Monthly average soil VWC at 10 and $40 \mathrm{~cm}$ depths (3.9 and $15.7 \mathrm{in}$ ) and soil water storage from 0 to $80 \mathrm{~cm}$ (0 to 31.5 in) did not statistically differ between treatments from 2012 through 2015. Soil VWC did significantly differ among drainage treatments at the $20 \mathrm{~cm}$ depth (7.9 in), but only during 2013 and 2014 (table 5). During this time, the shallow drainage treatment was significantly drier than the other treatments. Soil VWC at $60 \mathrm{~cm}$ (23.6 in) in the shallow drainage treatment was drier than the undrained treatment but similar to the controlled and conventional drainage systems in July, August, and September of 2012. Otherwise, monthly average soilVWC did not differ among the drainage treatments.

\section{Table 4}

Number of days that the water table is within $30 \mathrm{~cm}$ or between 30 and $60 \mathrm{~cm}$ of the ground surface during the growing season (April to October) from 2011 to 2015 for the four treatments: conventional drainage (Conv.), controlled drainage (CD), shallow drainage (SH), and no drainage (ND). Means within years or the five-year average with a different letter are significantly different $(p<0.05)$. Only years with significant differences have letters included.

\begin{tabular}{|c|c|c|c|c|c|c|c|c|}
\hline \multirow[b]{2}{*}{ Year } & \multicolumn{4}{|l|}{$30 \mathrm{~cm}$} & \multicolumn{4}{|c|}{30 to $60 \mathrm{~cm}$} \\
\hline & Conv. & CD & SH & ND & Conv. & CD & SH & ND \\
\hline 2011 & 1 & 0 & 0 & 6 & $4 b$ & $\mathrm{Ob}$ & $5 b$ & $61 a$ \\
\hline 2012 & 2 & 2 & 4 & 8 & 1 & 2 & 5 & 7 \\
\hline 2013 & $1 b$ & $2 b$ & $21 a b$ & $26 a$ & $6 b$ & $7 b$ & $21 a$ & $22 a$ \\
\hline 2014 & $\mathrm{Ob}$ & $1 a b$ & $9 a b$ & $21 a$ & $4 b$ & $6 b$ & $16 a$ & $16 a$ \\
\hline 2015 & 0 & 0 & 9 & 16 & 2 & 2 & 17 & 25 \\
\hline Average & $1 \mathrm{c}$ & $1 c$ & $9 b$ & $15 a$ & $3 b$ & $3 b$ & $13 b$ & $26 a$ \\
\hline
\end{tabular}

Overall, there were minimal occurrences when drainage treatment affected soil water metrics. This was unexpected since soil water contents and therefore soil water storage are a function of capillary rise above the water table height. The field capacity and low spatial variability in soil texture at the site may explain the lack of differences in VWC and soil water storage despite observed differences in the depth to water table. Water retention curves show little change in soil water contents (i.e., 0.36 to 0.34 $\mathrm{cm}^{3} \mathrm{~cm}^{-3}\left[0.36\right.$ to $\left.0.34 \mathrm{in}^{3} \mathrm{in}^{-3}\right]$ ) from matric potentials near saturation to field capacity (i.e., -50 and $-330 \mathrm{~cm} \mathrm{H}_{2} \mathrm{O}[-19.7$ and -129.9 in $\left.\mathrm{H}_{2} \mathrm{O}\right]$, respectively). This means these soils will have little difference in the amount of soil water in the unsaturated portions of the soil profile (i.e., capillary water) for all water table depths to $330 \mathrm{~cm}$ (10.8 ft) (Bachmann and van der Ploeg 2002; Jury and Horton 2004). The monthly time scale for comparison may also be too large to discern differences between drainage treatments due to capillary rise of water. The lack of differences in soil VWC between months and years, even though rainfall substantially differed from 2012 to 2015 , also supports this hypothesis.

Drainage. In Iowa, drainage typically occurs during mid to late March until late November when soils are unfrozen. In most years, the majority of drainage occurred in April, May, and June due to the timing of rainfall in the region. In 2011 and 2012, nearly $100 \%$ of total drainage from the conventionally drained treatment occurred during these months, but only 30\% in 2014 . In 2013 and 2015, over 50\% of drainage occurred from April to June. Annual average drainage volumes from the conventional treatment ranged from $7.8 \mathrm{~cm}$ (3.1 in) in 
Table 5

Average monthly volumetric water content $\left(\mathrm{cm}^{3} \mathrm{~cm}^{-3}\right)$ at $20 \mathrm{~cm}$ depth from 2012 to 2015 for the four treatments: conventional drainage (Conv.), controlled drainage (CD), shallow drainage (SH), and no drainage (ND). Means within months with a different letter are significantly different $(p<0.05)$. Only months with significant differences have letters included.

\begin{tabular}{|c|c|c|c|c|c|c|c|c|c|c|c|c|c|c|c|c|}
\hline \multirow[b]{2}{*}{ Month } & \multicolumn{4}{|l|}{2012} & \multicolumn{4}{|l|}{2013} & \multicolumn{4}{|l|}{2014} & \multicolumn{4}{|l|}{2015} \\
\hline & Conv. & CD & SH & ND & Conv. & CD & SH & ND & Conv. & CD & SH & ND & Conv. & CD & SH & ND \\
\hline Apr. & 0.35 & 0.33 & 0.28 & 0.30 & 0.34 & 0.33 & 0.29 & 0.33 & $0.32 a$ & $0.31 a$ & $0.21 b$ & $0.32 a$ & 0.32 & 0.32 & 0.25 & 0.32 \\
\hline June & 0.32 & 0.31 & 0.28 & 0.30 & $0.39 a$ & $0.37 a b$ & $0.28 b$ & $0.39 a$ & $0.38 a$ & $0.36 a b$ & $0.26 b$ & $0.37 a$ & 0.39 & 0.36 & 0.32 & 0.40 \\
\hline July & 0.21 & 0.24 & 0.20 & 0.17 & $0.33 a$ & $0.30 a$ & $0.18 b$ & $0.30 a$ & $0.37 a$ & $0.32 a b$ & $0.24 b$ & $0.33 a b$ & 0.37 & 0.35 & 0.31 & 0.38 \\
\hline Aug. & 0.25 & 0.26 & 0.21 & 0.18 & $0.27 a$ & $0.27 a$ & $0.15 b$ & $0.25 a b$ & $0.30 a$ & $0.27 a$ & $0.16 b$ & $0.22 a b$ & 0.35 & 0.33 & 0.30 & 0.35 \\
\hline Oct. & 0.34 & 0.31 & 0.31 & 0.30 & $0.32 a$ & $0.23 a b$ & $0.12 c$ & $0.19 b c$ & $0.35 a$ & $0.31 \mathrm{ab}$ & $0.25 b$ & $0.35 a$ & 0.34 & 0.32 & 0.29 & 0.33 \\
\hline
\end{tabular}

2012 to $39.7 \mathrm{~cm}$ (15.6 in) in 2014 (figure 2). Drainage for the controlled drainage treatment ranged from $4.1 \mathrm{~cm}$ (1.6 in) in 2012 to $21.8 \mathrm{~cm}$ ( $8.6 \mathrm{in})$ in 2013 , while drainage from the shallow treatment ranged from 5.9 to $18.7 \mathrm{~cm}$ (2.2 to $7.4 \mathrm{in})$ for the same years. The conventional drainage system produced significantly greater drainage volumes than the shallow drainage system in 2011 and significantly greater drainage volumes than both the shallow and controlled drainage systems in 2013, 2014, and for the five-year average (figure 2).

Over the five years of this study, controlled drainage reduced flow volumes by $60 \%$ while shallow drainage reduced flow by $58 \%$ when compared to the conventional drainage system. Helmers et al. (2012) reported average drainage flow reductions at this site in the shallow and controlled drainage treatments of $37 \%$ and $46 \%$, respectively, over the four-year period from 2007 to 2010. In comparison, the Skaggs et al. (2012) summary of 20 controlled drainage research sites indicated average drainage volume reductions ranged between $18 \%$ and $85 \%$. The shallow drainage systems in this study reduced drainage volumes by nearly three times as much as the $20 \%$ reduction reported by Sands et al. (2008) for a site in Minnesota where four of the five years in the study had average or below average rainfall. The initial four years after the drainage systems were installed at our site (2007 to 2010) had above average rainfall whereas years five through nine of this study had a mixture of below average and average rainfall (Helmers et al. 2012). The larger reductions in drainage volume from the drainage water management treatments reported here for years five through nine are likely due to a larger proportion of the field water balance going to crop uptake between rainfall events. Whereas, in years with above average rainfall, there was a higher proportion of the field water balance going to drainage from the drainage water management treatments due to high water tables throughout the season.

Flow reductions of controlled drainage compared to conventional drainage varied annually. The smallest statistically significant reduction, $40 \%$, from conventional drainage occurred in 2013. The flow from the controlled drainage treatment in 2014 was reduced $81 \%$ compared to conventional treatment. In both of these years (2013 and 2014), the water table control boards were installed to $76 \mathrm{~cm}$ (30 in) throughout the year. There were no statistically significant flow reductions in 2011, 2012, and 2015 for the controlled drainage treatment as compared to the conventional drainage system. In 2011, nearly all drainage occurred when the controlled drainage treatment was freely draining in spring, and 2012 was a severe drought. The flow reduction of the shallow drainage treatment compared to the conventional drainage system was also annually variable ranging from a decrease of $49 \%$ in 2013 to a decrease of $85 \%$ in 2011. Even though the majority of drainage during most years occurred when the controlled drainage treatments were freely draining, there were still drainage volume reductions. The shallow drainage treatment did not statistically differ from the controlled drainage treatment, indicating that both drainage water management practices were effective at reducing drainage volumes as compared to the conventional drainage system.

Nitrate-Nitrogen Loss. Annual flowweighted mean $\mathrm{NO}_{3}-\mathrm{N}$ concentrations of subsurface drainage waters in the shallow drainage treatment were significantly greater than the conventional and controlled drainage treatments during 2011 and when averaged across all five years (table 6). The $\mathrm{NO}_{3}-\mathrm{N}$ concentrations for the conventional drainage and controlled drainage treatments did not differ among each other. Burchell et al. (2005) also reported similar results with shallow drainage systems containing significantly greater flow weighted mean $\mathrm{NO}_{3}-\mathrm{N}$ concentrations than conventional drainage systems. Burchell et al. (2005) provided evidence of preferential water flows through the soil profile to the shallow drains and hypothesized that the water retention time in soils is too short for denitrification due to unsaturated flow near the drains both during and directly following rainfall events. In their review, Skaggs et al. (2012) reported that controlled drainage did not affect $\mathrm{NO}_{3}-\mathrm{N}$ concentrations of drainage waters in their overview of 20 controlled drainage experiments. However, Adeuya et al. (2012) reported that although there were no observable differences in $\mathrm{NO}_{3}-\mathrm{N}$ concentrations between their controlled drainage and conventional drainage treatments over the course of a full year, the controlled drainage treatment did reduce $\mathrm{NO}_{3}-\mathrm{N}$ concentrations during periods when crops were not actively growing. A similar observation was also observed by $\mathrm{Ng}$ et al. (2002) and was attributed to greater denitrification due to the higher water table. The southern replication (i.e., the Taintor soil series; Agriaquolls) in our study had statistically greater annual flow-weighted mean $\mathrm{NO}_{3}-\mathrm{N}$ concentrations in the drainage waters than the northern replication (i.e., the Kalona soil series; Endoaquolls). Due to shallower water tables in the northern replication in conjunction with the lack of differences in soil total $\mathrm{N}$, the lower drainage water $\mathrm{NO}_{3}-\mathrm{N}$ concentrations in the northern replication could be 


\section{Figure 2}

Average annual drainage volumes $(\mathrm{cm})$ from the three drainage treatments: conventional drainage (Conv.), controlled drainage (CD), and shallow drainage (SH). Years or the five-year average not connected with the same letter are statistically different $(p<0.05)$. Only years with significant differences have letters included.

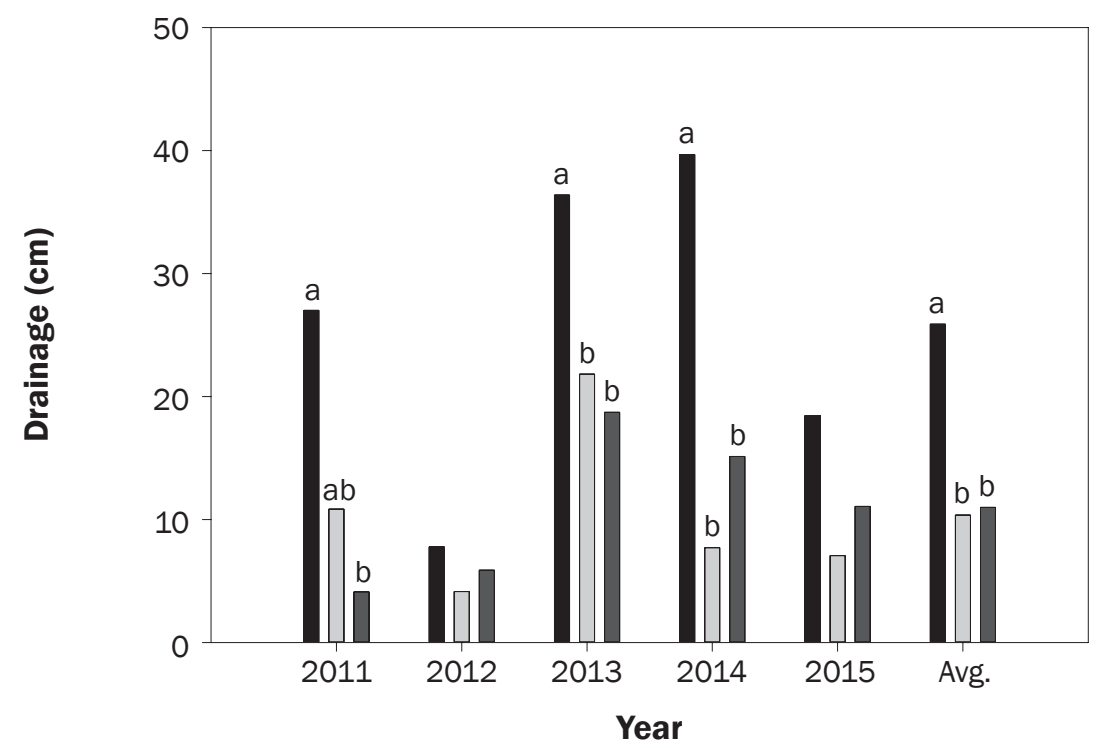

Legend

$\square$ Conv. $\square \mathrm{CD} \square \mathrm{SH}$

\section{Figure 3}

Average annual nitrate-nitrogen $\left(\mathrm{NO}_{3}-\mathrm{N}\right)$ loads $\left(\mathrm{kg} \mathrm{ha}^{-1}\right)$ for the three drainage treatments: conventional drainage (Conv.), controlled drainage (CD), and shallow drainage (SH). Years or the five- year average not connected with the same letter are statistically different $(p<0.05)$. Only years with significant differences have letters included.

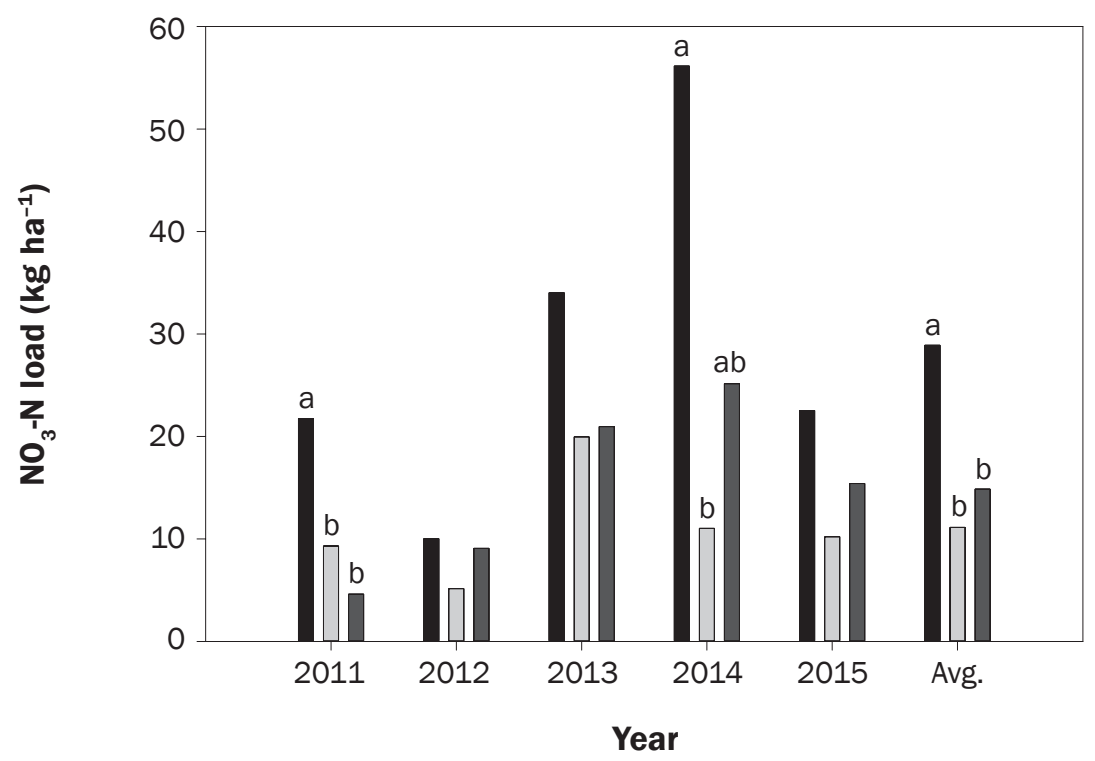

Legend

$\square$ Conv. $\square \mathrm{CD} \square \mathrm{SH}$

\section{Table 6}

Average annual flow-weighted nitratenitrogen $\left(\mathrm{NO}_{3}-\mathrm{N}\right)$ concentrations $\left(\mathrm{mg} \mathrm{L}^{-1}\right)$ from 2011 to 2015 for the three drainage treatments: conventional drainage (Conv.), controlled drainage (CD), and shallow drainage (SH). Means within years or the five-year average with a different letter are significantly different $(p<0.05)$. Only years with significant differences have letters included.

\begin{tabular}{llll}
\hline Year & Conv. & CD & SH \\
\hline 2011 & $8 b$ & $9 a b$ & $11 a$ \\
2012 & 13 & 12 & 14 \\
2013 & 9 & 9 & 11 \\
2014 & 14 & 14 & 16 \\
2015 & 12 & 14 & 14 \\
Avg. & $11 b$ & $12 b$ & $13 a$
\end{tabular}

an indication of greater denitrification due to anaerobic conditions in the saturated soils.

Nitrate-N loads from the conventionally drained treatment varied from 10 to 56.1 $\mathrm{kg} \mathrm{ha}^{-1}$ (8.9 to $50.1 \mathrm{lb} \mathrm{ac}^{-1}$ ) (figure 3). The $\mathrm{NO}_{3}-\mathrm{N}$ loads from the controlled drainage treatment varied from 5.1 to $20 \mathrm{~kg} \mathrm{ha}^{-1}$ (4.6 to $17.8 \mathrm{lb} \mathrm{ac}^{-1}$ ). The $\mathrm{NO}_{3}-\mathrm{N}$ loads from the shallow drainage treatment ranged from 4.6 to $25.1 \mathrm{~kg} \mathrm{ha}^{-1}$ (4.1 to $22.4 \mathrm{lb} \mathrm{ac}^{-1}$ ). The controlled drainage treatment significantly reduced $\mathrm{NO}_{3}-\mathrm{N}$ loads in 2011 and 2014 and the shallow drainage treatment reduced $\mathrm{NO}_{3}-\mathrm{N}$ loads in 2011 when compared to the conventionally drained treatment. This is most likely because the shallow drained treatment had lower flow volume but higher flow-weighted $\mathrm{NO}_{3}-\mathrm{N}$ concentrations.

Controlled drainage significantly reduced $\mathrm{NO}_{3}-\mathrm{N}$ loads by $61 \%$ over the five years when compared to conventional drainage while shallow drainage also had significant reductions of $49 \%$. Helmers et al. (2012) reported overall reductions of $36 \%$ and $29 \%$ for controlled and shallow drainage treatments, respectively, for the years 2007 to 2010 at this site. Similar to the drainage volume reductions, the $\mathrm{NO}_{3}-\mathrm{N}$ load reductions across the five years of this study were at the higher end of the values (i.e., 18\% to 79\%) reported by Skaggs et al. (2012) and are much higher than the $18 \%$ reductions reported by Sands et al. (2008).

Crop Yield. The undrained treatments reduced the five-year average corn yields by $6 \%$ compared with conventional drainage (figure 4). Unlike the corn yields reported for 2007 to 2010 at this site, the controlled drainage did not reduce corn yields from 2011 to 2015 (Helmers et al. 2012). Skaggs 
Figure 4

Annual and five-year average corn yields $\left(\mathrm{kg} \mathrm{ha}^{-1}\right)$ for the four treatments: conventional drainage (Conv.), controlled drainage (CD), shallow drainage (SH), and no drainage (ND). Means within years or the five-year average with a different letter are significantly different $(p<0.05)$. Only years with significant differences have letters included.

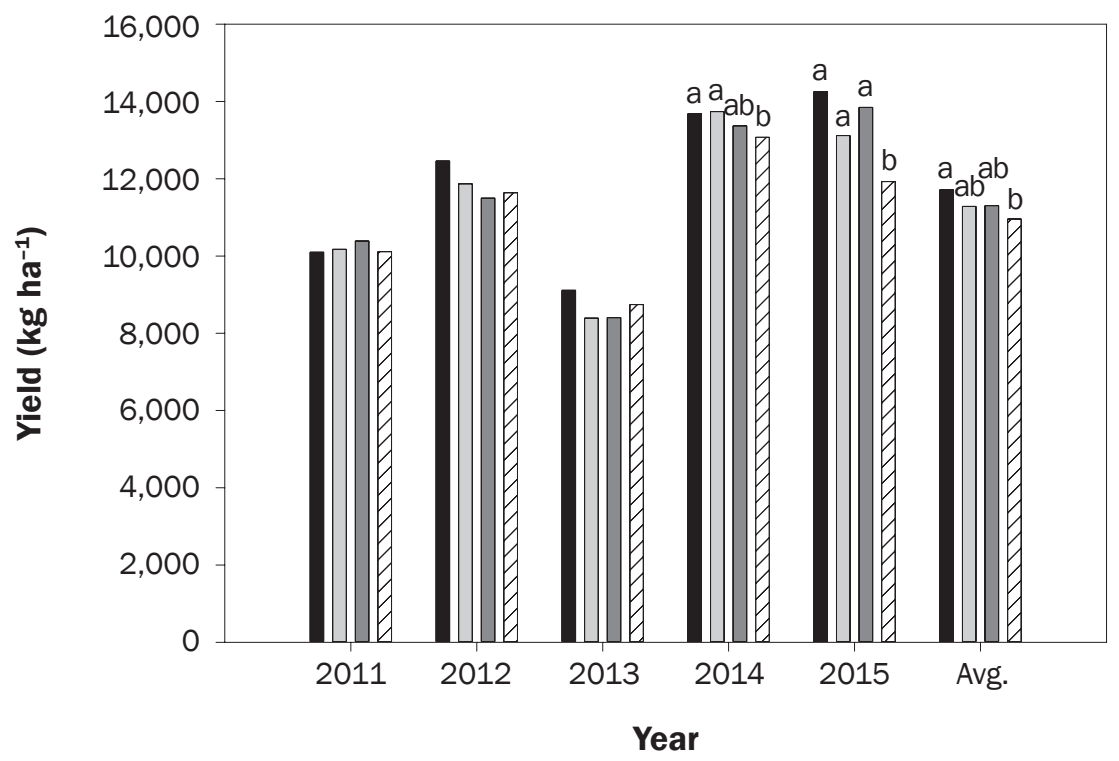

Legend

$\square$ Conv. $\square \mathrm{CD} \square \mathrm{SH} \mathrm{V} / \mathrm{ND}$

Figure 5

Annual and five-year average soybean yields $\left(\mathrm{kg} \mathrm{ha}^{-1}\right)$ for the four treatments: conventional drainage (Conv.), controlled drainage (CD), shallow drainage (SH), and no drainage (ND). Means within years or the five-year average with a different letter are significantly different $(p<0.05)$. Only years with significant differences have letters included.

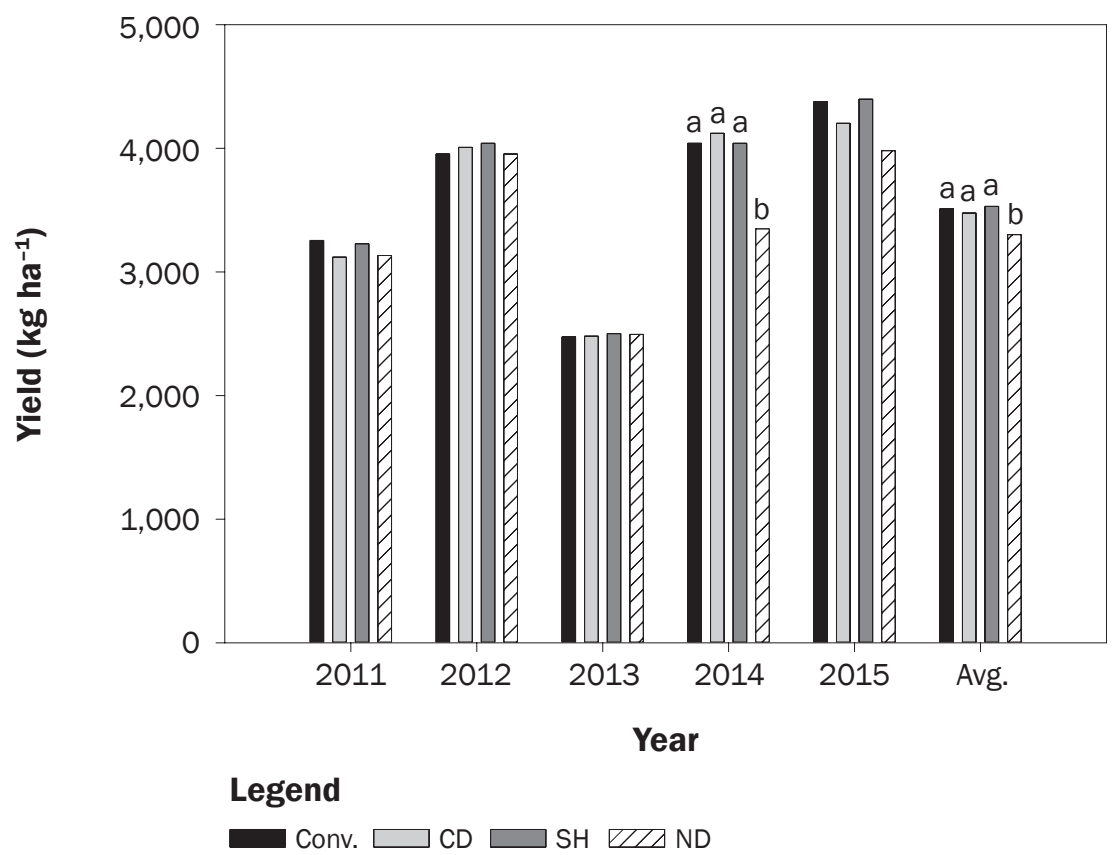

et al. (2012) reported drainage water management impacts on corn yields ranging from no effect to a $19 \%$ increase over conventional drained fields. Even with the lack of active water table management during the summer months, regardless of the rainfall amount, there was no corn yield decrease. The northern replication had statistically lower corn yields when compared to the southern replication. The northern replication also had statistically shallower water tables and statistically lower $\mathrm{NO}_{3}-\mathrm{N}$ concentrations. While the shallow water tables seemed to enhance denitrification, they also seem to have negatively affected corn yields.

There were also no soybean yield differences between the conventional, shallow, and controlled drainage treatments (figure 5). Similar to the corn yields, the undrained treatment reduced soybean yields by $6 \%$ when compared to the conventional drainage system. These results, like the corn yields, are consistent with Skaggs et al. (2012) who reported drainage water management effects on soybean yields ranging from no effect to a $10 \%$ increase.

\section{Summary and Conclusions}

This study showed that over the five-year study, which contained three years of average and two years of below average rainfall, drainage water management reduced drainage volume and $\mathrm{NO}_{3}-\mathrm{N}$ losses. Controlled and shallow drainage reduced annual flow by $60 \%$ and $58 \%$ while reducing $\mathrm{NO}_{3}-\mathrm{N}$ loads by $61 \%$ and $49 \%$, respectively, when compared to conventional drainage. Although more water and nitrates may reach the shallow groundwater, the flow transport and anoxic conditions of the groundwater system may promote denitrification and the potential to remove $\mathrm{N}$ via gaseous losses. These reductions were greater than the reductions reported for the years 2007 to 2010 when rainfall was above normal. These results are consistent with the literature indicating average drainage volume reductions between $18 \%$ and $85 \%$ and $\mathrm{NO}_{3}-\mathrm{N}$ reductions between $18 \%$ and $79 \%$. Soybean and corn yields were also congruent with previous studies indicating no yield differences between drainage water management and conventional drainage treatments.

Drainage treatment had an effect on the water table but not on soil VWC, unlike what was predicted by others' reports. The undrained treatment had the shallowest 
water table and greatest number of days that the water table was within $30 \mathrm{~cm}$ (12 in) of the surface, which can negatively affect crop production. There was limited difference between conventional, shallow, and controlled drainage treatments in the number of days the water table was within $30 \mathrm{~cm}$ of the ground. Even with the shallower water tables found in the undrained, shallow, and controlled drainage treatments, there was no difference in soil VWC between any of the treatments, likely due to capillary rise in this soil type. Overall, this study illustrated that drainage is important for agricultural production, and drainage water management reduced $\mathrm{NO}_{3}-\mathrm{N}$ loss by reducing drainage volume under the conditions of this study.

\section{Acknowledgements}

This research is part of a regional collaborative project supported by the USDA National Institute of Food and Agriculture (NIFA), Award No. 2011-68002-30190, Cropping Systems Coordinated Agricultural Project: Climate Change, Mitigation, and Adaptation in Corn-based Cropping Systems. Research data and supporting metadata are stored in the team's centralized Climate and Cropping Systems database.

\section{References}

Adeuya, R., N. Utt, J. Frankenberger, L. Bowling, E. Kladivko, S. Brouder, and B. Carter. 2012. Impacts of drainage water management on subsurface drain flow, nitrate concentration, and nitrate loads in Indiana. Journal of Soil and Water Conservation 67(6):474-484, doi:10.2489/jswc.67.6.474.

Bachmann, J., and R.R. van der Ploeg. 2002. A review on recent development in soil water retention theory: Interfacial tension and temperature effects. Journal of Plant Nutrition and Soil Science 165:468-478.

Basche, A.D., T.C. Kaspar, S.V. Archontoulis, D.B. Jaynes, T.J. Sauer, T.B. Parkin, and F.E. Miguez. 2016. Soil water improvements with the long-term use of a winter rye cover crop. Agricultural Water Management 172:40-50.

Burchell, M.R., R.W. Skaggs, G.M. Chescheir, J.W. Gilliam, and L.A. Arnold. 2005. Shallow subsurface drains to reduce nitrate losses from drained agricultural lands. Transactions of the American Society of Agricultural Engineers (ASAE) 48(3):1079-1089.

Daigh, A.L.M., X. Zhou, M.J. Helmers, C.H. Pederson, R. Horton, M. Jarchow, and M. Liebman. 2015. Subsurface drainage nitrate and total reactive phosphorus losses in bioenergy-based prairie and corn systems. Journal of Environmental Quality 44:1638-1646.

David, M., L. Drinkwater, and G. Mclsaac. 2010. Sources of nitrate yields in the Mississippi River Basin. Journal of Environmental Quality 39:1657-1667.
Drury, C.F., C.S. Tan, J.D. Gaynor, T.O. Oloya, I.J. Van Wesenbeeck, and D.J. McKenney. 1997. Optimizing corn production and reducing nitrate losses with water table control-subirrigation. Soil Science Society of America Journal 61(3):889-895.

Frankenberger, J., E. Kladivko, G. Sands, D. Jaynes, N Fausey, M. Helmers, R. Cooke, J. Strock, K. Nelson, and L. Brown. 2007. Questions and Answers about Drainage Water Management for the Midwest, Purdue Extension Publication WQ-44. West Lafayette, IN: Purdue Extension.

Helmers, M.J., R. Christianson, G. Brenneman, D. Lockett, and C. Pederson. 2012. Water table, drainage, and yield response to drainage water management in southeast Iowa. Journal of Soil and Water Conservation 67(6):495-501, doi:10.2489/jswc.67.6.495.

Herzmann, D.E., L.J. Abendroth, and L.D. Bunderson. 2014. Data management approach to multidisciplinary agricultural research and syntheses. Journal of Soil and Water Conservation 69(6):180A-185A, doi:10.2489/ jswc.69.6.180A

Jury, W., and R. Horton. 2004. Soil Physics, 6th Ed. Hoboken, NJ: Wiley.

Kladivko, E.J., M.J. Helmers, L.J. Abendroth, D. Herzmann, R. Lal, M. Castellano, D.S. Mueller, J.E. Sawyer, R.P. Anex, R.W. Arritt, B. Basso, J.V. Bonta, L. Bowling, R.M. Cruse, N.R. Fausey, J. Frankenberger, P. Gassman, A.J. Gassmann, C.L. Kling, A. Kravchenko, J.G. Lauer, F.E. Miguez, E.D. Nafziger, N. Nkongolo, M. O'Neal, L.B. Owens, P. Owens, P. Scharf, M.J. Shipitalo, J.S. Strock, and M.B. Villamil. 2014. Standardized research transdisciplinary research of climate variation impacts in corn production systems. Journal of Soil and Water Conservation 69(6):532-542, doi:10.2489/jswc.69.6.532.

Lauer, J. 2008. Flooding impacts on corn growth and yield. Field Crops 28:49-56.

Lizaso, J.I., and J.R. Ritchie. 1997. Maize shoot and root response to root zone saturation during vegetative growth. Agronomy Journal 89:125-134.

Madramootoo, C.A., G.E. Dodds, and A. Papadopoulos. 1993. Agronomic and environmental benefits of watertable management. Journal of Irrigation and Drainage Engineering 119(6):1052-1065.

Martinez-Feria, R.A., R. Dietzel, M. Liebman, M.J. Helmers, and S.V. Archontoulis. 2016. Rye cover crop effects on maize: A system-level analysis. Field Crops Research 196:145-159.

Munns, R. 2002. Comparative physiology of salt and water stress. Plant Cell and Environment 25:239-250.

Ng, H.Y.F., C.S. Tan, C.F. Drury, and J.D. Gaynor. 2002 Controlled drainage and subirrigation influences tile nitrate loss and corn yields in a sandy loam soil in Southwestern Ontario. Agriculture, Ecosystems and Environment 90(1):81-88.

Passioura, J.B., and R. Munns. 2000. Rapid environmental changes that affect leaf water status induce transient surges or pauses in leaf expansion rate. Australian Journal of Plant Physiology 27:941-948.

Sands, G.R., I. Song, L.M. Busman, and B.J. Hansen. 2008. The effects of subsurface drainage depth and intensity on nitrate loads in the northern Cornbelt. Transactions of the American Society of Agricultural and Biological Engineers (ASABE) 51(3):937-946.

SAS. 2011. SAS User's Guide. Ver. 9.3. Cary, NC: SAS Institute, Inc.

Skaggs, R.W., and G.M. Chescheir III. 2003. Effects of subsurface drain depth on nitrogen losses from drained lands. Transactions of the American Society of Agricultural and Biological Engineers (ASABE) 46(2):237-244.

Skaggs, R.W., N.R. Fausey, and R.O. Evans. 2012. Drainage water management. Journal of Soil and Water Conservation 67(6):167-172, doi:10.2489/ jswc.67.6.167A.

Skaggs, R.W., and J. van Schilfgaarde. 1999. Agricultural Drainage. Agronomy Monograph 38, Madison, WI: American Society of Agronomy, Crop Science Society of America, and Soil Science Society of America.

Strock, J.S., G.R. Sands, and M.J. Helmers. 2011. Subsurface Drainage Design and Management to Meet Agronomic and Environmental Goals. In Soil Management: Building a Stable Base for Agriculture, eds. J.L. Hatfield and T.J. Sauer, 199-208. Madison, WI: American Society of Agronomy, Crop Science Society of America, and Soil Science Society of America.

Turner, R.E., and N.N. Rabalais. 1994. Coastal eutrophication near the Mississippi River Delta. Nature 368(6472):619-621. 